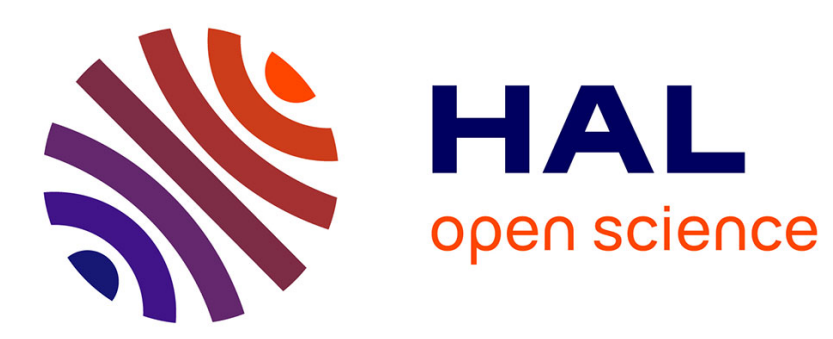

\title{
The impact of eucalypt on the leaf-associate aquatic hyphomycetes in Spanish streams
}

Eric Chauvet, Eric Fabre, Arturo Elosegi, Jesús Pozo

\section{To cite this version:}

Eric Chauvet, Eric Fabre, Arturo Elosegi, Jesús Pozo. The impact of eucalypt on the leafassociate aquatic hyphomycetes in Spanish streams. Botany / Botanique, 1997, 75 (6), pp.880-887. 10.1139/b97-097\#.V-OHxjVgn9Q . hal-01376545

\section{HAL Id: hal-01376545 \\ https://hal.science/hal-01376545}

Submitted on 5 Oct 2016

HAL is a multi-disciplinary open access archive for the deposit and dissemination of scientific research documents, whether they are published or not. The documents may come from teaching and research institutions in France or abroad, or from public or private research centers.
L'archive ouverte pluridisciplinaire HAL, est destinée au dépôt et à la diffusion de documents scientifiques de niveau recherche, publiés ou non, émanant des établissements d'enseignement et de recherche français ou étrangers, des laboratoires publics ou privés. 


\section{Open Archive TOULOUSE Archive Ouverte (OATAO)}

OATAO is an open access repository that collects the work of Toulouse researchers and makes it freely available over the web where possible.

This is an author-deposited version published in : http://oatao.univ-toulouse.fr/ Eprints ID : 16128

To link to this article : DOI : 10.1139/b97-097\#.V-OHxjVgn9Q URL : http://dx.doi.org/10.1139/b97-097\#.V-OHxjVgn9Q

To cite this version : Chauvet, Eric and Fabre, Eric and Elosegui, Arturo and Pozo, Jesus The impact of eucalypt on the leaf-associated aquatic hyphomycetes in Spanish streams. (1997) Canadian Journal of Botany, vol. 75, n6, pp. 880-887. ISSN 1916-2790

Any correspondence concerning this service should be sent to the repository administrator: staff-oatao@ listes-diff.inp-toulouse.fr 


\title{
The impact of eucalypt on the leaf-associated aquatic hyphomycetes in Spanish streams
}

\author{
Eric Chauvet, Eric Fabre, Arturo Elósegui, and Jesús Pozo
}

\begin{abstract}
Aquatic hyphomycete assemblages on decomposing leaf litter of the exotic species Eucalyptus globulus Labill. were compared with those on the native riparian species Alnus glutinosa (L.) Gaertn. in three low-order streams of the Agüera watershed (Basque Country - Cantabria, Spain). These streams contrast by the importance of eucalypt in the riparian vegetation and by the nutrient contents in the water. Neither the total conidial production nor the number of fungal species differed between the two leaf species in any of the streams. Fungal colonization of eucalypt leaves appeared to be delayed by about 2 weeks, probably owing to their high content in inhibitory constituents. While Flagellospora curvula Ingold largely dominated pioneer assemblages on both leaf species, the second most important species, Lunulospora curvula Ingold, exhibited a preference for eucalypt. In the stream surrounded by eucalypt, the fungal diversity was surprisingly lower on eucalypt than on alder. In the stream with higher orthophosphate concentrations, the conidial production was similarly increased on both leaf species. The present data together with recent results from a similar investigation in Portugal suggest a minor impact of eucalypt on the activity and diversity of aquatic hyphomycete leaf-associated assemblages in southern European streams.
\end{abstract}

Key words: aquatic hyphomycetes, eucalypt, alder, leaf litter, stream.

\begin{abstract}
Résumé : Les communautés d'hyphomycètes aquatiques associées aux litières en décomposition de l'espèce exotique Eucalyptus globulus Labill. ont été comparées à celles de l'espèce riveraine indigène Alnus glutinosa (L.) Gaertn. dans trois rivières de faible numéro d'ordre du bassin de l'Agüera (Pays Basque - Cantabrique, Espagne). Ces rivières contrastent par l'importance de l'eucalyptus dans la végétation riveraine et par les teneurs en nutriments dans l'eau. Quelle que soit la rivière, ni la production conidienne totale, ni le nombre d'espèces fongiques des deux espèces foliaires ne differrent. La colonisation fongique des feuilles d'eucalyptus apparait seulement retardée d'environ deux semaines, en raison probablement de leurs fortes teneurs en composés inhibiteurs. Alors que Flagellospora curvula Ingold domine largement les assemblages pionniers sur les deux espèces foliaires, la seconde espèce en importance, Lunulospora curvula Ingold, marque une préférence pour l'eucalyptus. Dans la rivière entourée d'eucalyptus, la diversité fongique est curieusement plus faible sur l'eucalyptus que sur l'aulne. Dans la rivière caractérisée par les plus fortes teneurs en orthophosphates, la production conidienne est augmentée de façon identique sur les deux substrats foliaires. Les présentes données associées aux résultats d'une étude semblable au Portugal suggèrent un impact mineur de l'eucalyptus sur l'activité et la diversité des communautés d'hyphomycètes aquatiques associées aux litières dans les rivières du Sud de l'Europe.
\end{abstract}

Mots clés : hyphomycètes aquatiques, eucalyptus, aulne, litière, rivières.

\section{Introduction}

The eucalypt (Eucalyptus globulus Labill.), a species originating from South Australia, was introduced to the Iberian Peninsula in 1829 (Bärlocher et al. 1995; Mitchell 1974). Plantations of this species now occupy large areas in northern Spain and central Portugal (Bärlocher et al. 1995; Basaguren and Pozo 1994). This large-scale replacement of native deciduous and pine trees by eucalypt led to dramatic alterations of the forest ecosystem, both in terms of nutrient cycling

E. Chauvet ${ }^{1}$ and E. Fabre. Centre d'Ecologie des Systèmes Aquatiques Continentaux (CNRS-UPS) 29 rue Jeanne Marvig, 31055 Toulouse Cédex 4, France.

A. Elósegui and J. Pozo. Laboratorio de Ecología, Facultad de Ciencias, Universidad del Pais Vasco, Apartado 644, 48080 Bilbao, Spain.

I Author to whom all correspondence should be addressed. email: chauvet@cesac.cemes.fr and of the associated biodiversity. Moreover, since leaf litter constitutes the main energy source for forested streams (Cummins 1988; Maltby 1992), this substitution has been suspected to result in major changes in the functioning of the stream ecosystem. The type (leaves, but also bark and branches) and timing (typical summer fall) of litter inputs to the stream differ markedly from those of native deciduous trees like alder, beech, and oak. The high content in polyphenols and the tough texture of eucalypt leaves are additional factors that may affect the stream biota.

Studies examining the effect of eucalypt on European streams are rare and, because the recent extension of eucalypt plantations mainly concerns southwestern Europe, are essentially restricted to Spain (Basaguren and Pozo 1994; Pozo 1993) and Portugal (Abelho and Graça 1996; Bärlocher et al. 1995). These studies have documented the processing of eucalypt litter and the associated macroinvertebrate and fungal biota. In northern Spain, eucalypt appears to decompose more slowly than alder, but this difference tends to decrease at sites characterized by higher nutrient concentrations in stream water and by the presence of eucalypt in the 
Table 1. Ranges of physical and chemical characteristics of the stream water at the three sites over the experimental period.

\begin{tabular}{lccc}
\hline & A & B & C \\
\hline Temperature $\left({ }^{\circ} \mathrm{C}\right)$ & $5.7-12.4$ & $9.0-14.8$ & $7.7-13.7$ \\
Suspended matter $(\mathrm{mg} / \mathrm{L})$ & $1.7-20.8$ & $1.7-40.2$ & $2.2-28.1$ \\
$\mathrm{pH}$ & $7.0-7.8$ & $7.8-8.8$ & $6.3-7.2$ \\
Conductivity $(\mu \mathrm{S} / \mathrm{cm})$ & $84-120$ & $104-260$ & $56-72$ \\
Oxygen concentration (\% of saturation) & $92-110$ & $96-112$ & $94-103$ \\
Orthophosphate concentration $(\mu \mathrm{g}$ P/L) & $2.7-7.5$ & $3.0-25.2$ & $2.1-5.0$ \\
Nitrate concentration (mg N/L) & $0.46-1.47$ & $0.34-1.07$ & $0.09-0.80$ \\
Ammonium concentration $(\mu \mathrm{g} \mathrm{N} / \mathrm{L})$ & $0-59$ & $0-52$ & $3-38$ \\
\hline
\end{tabular}

riparian vegetation (Pozo 1993; Pozo et al. 1997). The slower processing of eucalypt leaves has been attributed to the delay of leaf conditioning by microbes (Bärlocher et al. 1995) and the subsequently delayed and lower consumption by shredders (Basaguren and Pozo 1994). The delay of fungal colonization on eucalypt appeared to be due to inhibitory leaf constituents like phenolics, tannins, and lipids (Bärlocher et al. 1995). However, the only study that has examined the colonization of eucalypt by aquatic hyphomycetes in European streams demonstrated similar species richness on eucalypt and alder leaves and a slightly higher spore production from eucalypt (Bärlocher et al. 1995). This would suggest that, contrary to expectations, eucalypt may constitute a suitable substrate for fungal colonization and does not differ from native riparian species. This surprising result contrasts with earlier observations from Australia where eucalypt leaves appear to support a low number of aquatic hyphomycete species (Cowling and Waid 1963; Bunn 1986). Whether this phenomenon depends on the species considered remains unknown, but the variable quality of eucalypt leaves among the 800 species and hybrids known to date (Mitchell 1988) tends to support this hypothesis.

The present study is the first report for Spain, and the second for Europe, on the effect of eucalypt on the leafassociated microflora in streams. An experiment has been designed to take into account the influences of the leaf substrate (E. globulus vs. Alnus glutinosa (L.) Gaertn.) and of the other environmental conditions on the leaf colonization by aquatic hyphomycetes. The conidial production and the specific composition of the fungal communities on leaves were followed during a 6-month leaf decomposition experiment in three low-order streams located in the Agüera watershed (Basque Country, Cantabria). The main purpose of this study was to document the influence of eucalypt on the sporulation activity and the composition and diversity of the leaf-associated aquatic hyphomycete communities in streams.

\section{Materials and methods}

\section{Study sites}

The study was conducted in the Agüera Stream watershed (Basque Country - Cantabria, northern Spain; Fig. 1). The Agüera is a $30-\mathrm{km}$, low-order river system whose upstream section flows through a natural mixed deciduous Atlantic forest while the downstream section to the Atlantic Ocean is surrounded by pasture lands and pine and eucalypt plantations. Chemical characteristics indicate fresh, well-oxygenated water with relatively low nutrient levels at all three sites (Table 1), although site $\mathrm{B}$, which received the effluents from three villages, had orthophosphate concentrations on average three times higher than those of the two other sites. Site A was located on an upstream reach (first-order stream, altitude $350 \mathrm{~m}$ ) and surrounded by a natural mixed forest. On the downstream part of the Agüera, site B (third-order stream, altitude $80 \mathrm{~m}$ ) was influenced by a riparian vegetation including deciduous native trees and eucalypt ( $E$. globulus). Site C was located near site B on a tributary (first-order stream) and was exclusively covered by eucalypt. More complete descriptions of the Agüera watershed are given in González et al. (1994), and Elósegui and Pozo (1994).

\section{Sampling procedures}

One day before the beginning of the experiment, fresh leaves of alder and eucalypt were collected just after abscission from the ground at site $\mathbf{B}$. In the laboratory, leaves were weighed into portions of about $15 \mathrm{~g}$ fresh mass and enclosed in mesh bags $(20 \times 25 \mathrm{~cm}, 5-\mathrm{mm}$ mesh). Leaf bags were stored overnight in plastic bags placed in a refrigerator. On 16 November 1994, 144 leaf bags (i.e., 4 replicates $\times 2$ leaf species $\times 3$ sites $\times 6$ dates) were brought to the study sites and attached to large pebbles. After 1, 3, 8, 14, 20, and 26 weeks of immersion, four bags of each leaf species at each site were retrieved and returned to the laboratory. On each sampling occasion and at intermediate dates, the temperature, $\mathrm{pH}$, conductivity, and oxygen concentration of the water were measured and the nitrate and orthophosphate contents of the filtered water determined according to standard procedures (Elósegui and Pozo 1994). Leaf mass loss was determined by difference between the initial and the remaining dry mass of leaf packs.

Conidial production and structure of the fungal community One leaf of alder and two pieces of eucalypt leaves, or an equivalent surface of decomposed leaves, were randomly selected from each leaf bag and placed in $250 \mathrm{~mL}$ Erlenmeyer flasks containing $100 \mathrm{~mL}$ of filtered water (Millipore HA, $0.45 \mu \mathrm{m}$ ) from the corresponding site. Leaves were incubated on a rotary shaker $(60 \mathrm{rpm})$ for 2 days at $10^{\circ} \mathrm{C}$ to induce sporulation of aquatic hyphomycetes. The incubation was stopped by removing the leaves and adding $15 \mathrm{~mL}$ of $35 \%$ formalin, which preserved the conidia. The conidial suspension was made up to $250 \mathrm{~mL}$ with water. To ensure a uniform distribution of conidia, $250 \mu \mathrm{L}$ of a $0.5 \%$ Triton X-100 (Prolabo, France) solution were added to this suspension, the suspension was mixed, and $2-50 \mathrm{~mL}$ were filtered on Whatman cellulose nitrate filter (25-mm diameter, 5- $\mu \mathrm{m}$ porosity). Filters were fixed and stained with a solution of lactic acid $(600 \mathrm{~mL} / \mathrm{L}$ of $90 \%$ lactic acid) and Trypan blue $(500 \mathrm{mg} / \mathrm{L})$. Two filters per sample were prepared, and at least 100 conidia per filter were counted and identified to species by microscopic examinations at $\times 200$ or $\times 400$ magnification. Counts were standardized by the remaining leaf dry mass and the duration of incubation (in days). An index of conidial diversity, the $V^{\prime}$ equitability index (Hurlbert 1971), was calculated for each 
Fig. 1. Location of the three study sites in the Agüera watershed.

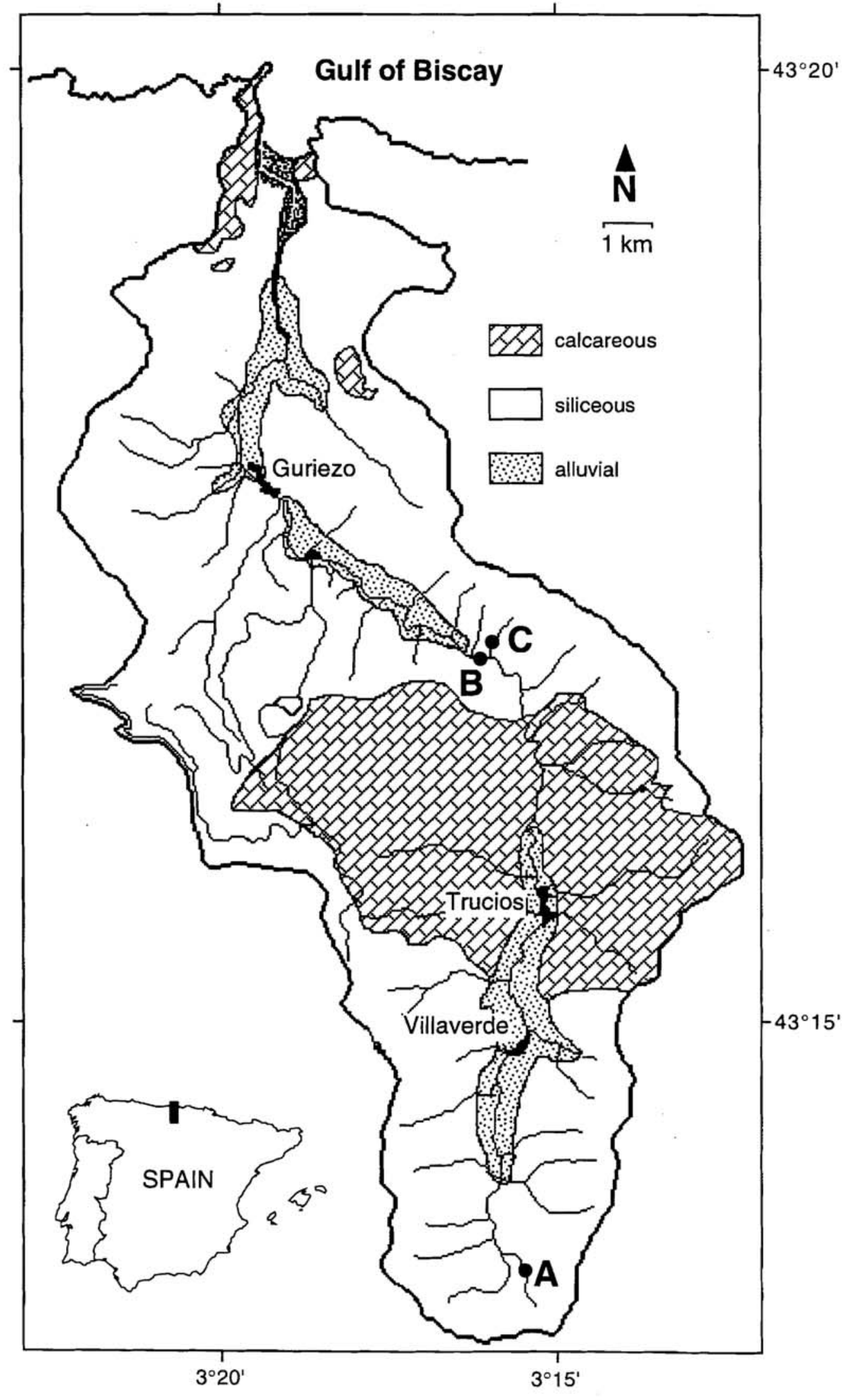


Fig. 2. Conidial production, number of species, and equitability of aquatic hyphomycete communities on alder (open bars) and eucalypt (solid bars) leaves at the three sites. Data at week 0 refer to the conidial production on leaves before their introduction to the stream. Note that the species, Tetracladium marchalianum, present on some eucalypt leaves at this time had a very low conidial production. Conidial production on alder at site B (week 14) and site C (week 26) could not be measured because of insufficient leaf material.

Site A

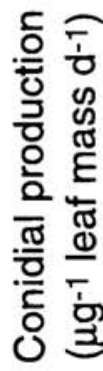

Site B
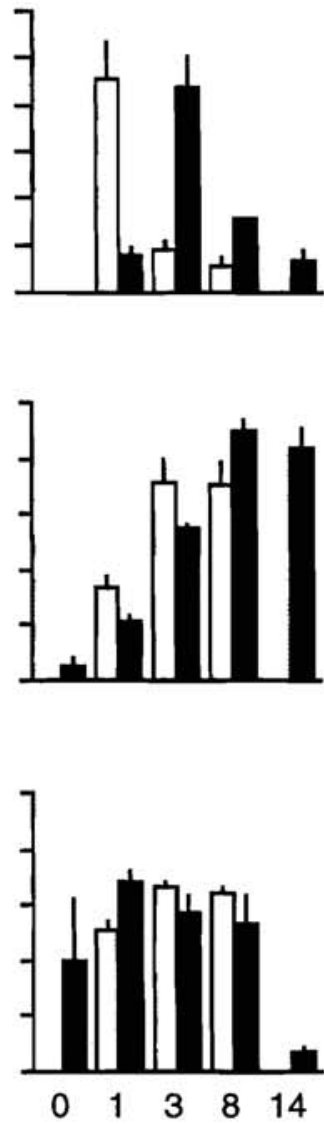

Site C

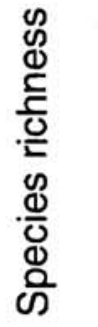
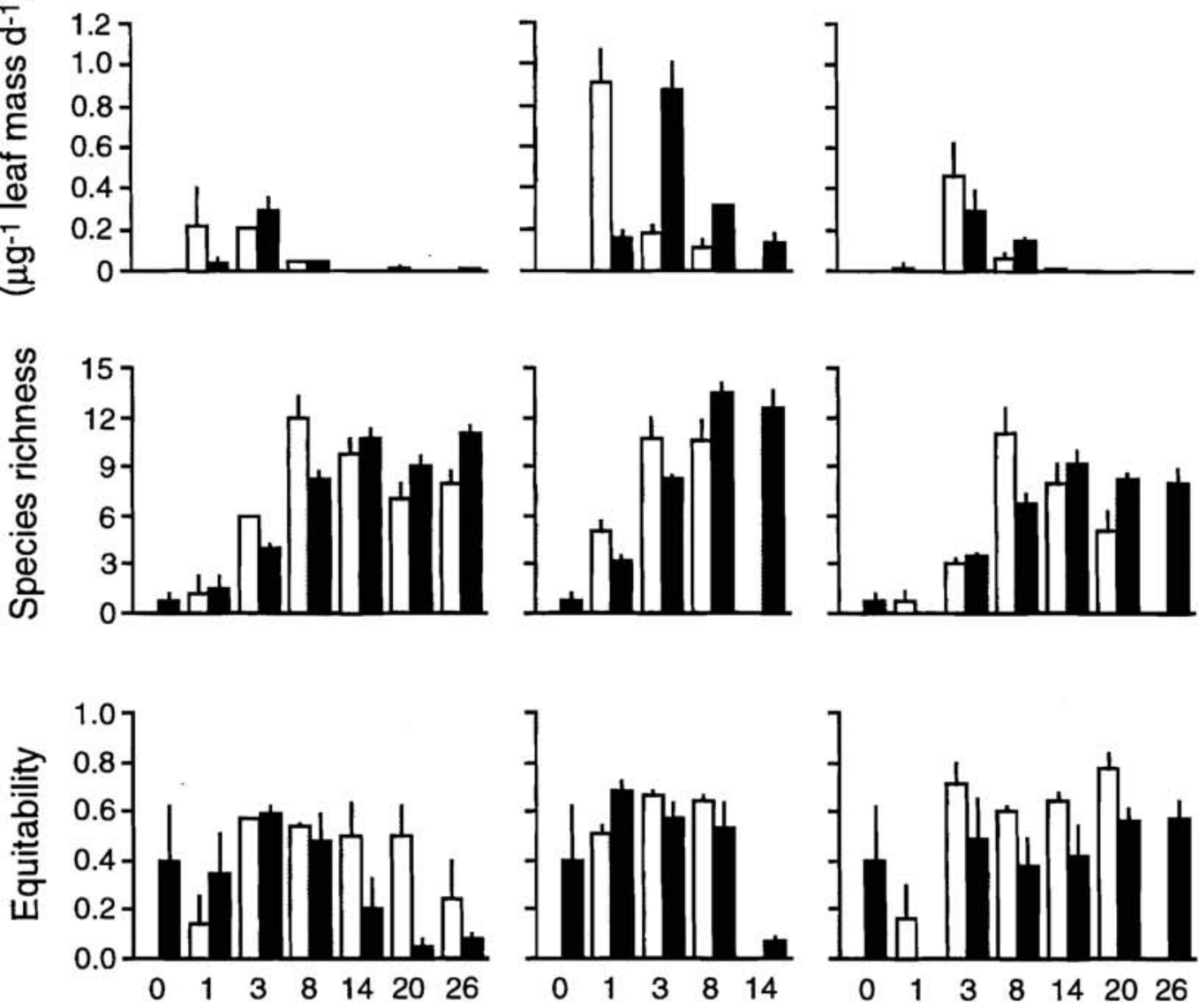

\section{time (week)}

date from the Shannon-Weaver function (Shannon and Weaver 1949) according to Krebs (1989).

\section{Results}

At the three sites, conidial production on alder and eucalypt leaves was of the same order of magnitude and exhibited a highly dynamic pattern (Fig. 2). The sporulation peak on alder appeared after only 1 week (site B), 3 weeks (site C), or an intermediate time (site A), while it occurred after 3 weeks at all three sites on eucalypt. As a consequence, the pattern of sporulation at the three sites generally appeared to be delayed on eucalypt by about 2 weeks. Site B exhibited the highest sporulation activity on both species, with the maximum on alder and eucalypt being two to four times those at the two other sites.

The numbers of aquatic hyphomycete species observed on alder and eucalypt leaves were generally similar (Fig. 2).
The observed pattern was a regular increase of the species richness up to a maximum after 3-14 weeks; the ranges for these maxima at the three sites were 11-12 species on alder and 9-13 on eucalypt. As with conidial production, a lag was noticed on eucalypt. The maximum species richness on alder was reached after 3 weeks at site B and 14 weeks at sites $\mathrm{A}$ and $\mathrm{C}$, whereas it was attained on eucalypt leaves after 8 and 14 weeks, respectively. A substantial number of species still occurred after 14 weeks on both species (except on alder at site B), whereas conidial production was very low. Unlike the production of conidia, the number of species was roughly similar at the three sites. The total number of species on these sites ranged from 15 to 17 on alder and from 15 to 18 on eucalypt (Table 2 ).

The diversity of the fungal community was similar on alder and eucalypt both at sites A and B (Fig. 2). In contrast, the diversity at site $\mathbf{C}$ was consistently lower on eucalypt. The temporal dynamic of the diversity was generally less 
Table 2. Relative abundance of aquatic hyphomycete species to the conidial production on alder and eucalypt leaves at the three sites over the experimental period (expressed as \%).

\begin{tabular}{|c|c|c|c|c|c|c|}
\hline \multirow[b]{2}{*}{ Species } & \multicolumn{2}{|c|}{ A } & \multicolumn{2}{|r|}{ B } & \multicolumn{2}{|c|}{$\mathrm{C}$} \\
\hline & Alder & Eucalypt & Alder & Eucalypt & Alder & Eucalypt \\
\hline Alatospora acuminata Ingold & 0.76 & 0.46 & 1.34 & 1.45 & 0.46 & 0.16 \\
\hline Anguillospora crassa Ingold & & & 0.02 & & & \\
\hline Anguillospora longissima (Sacc. et Sydow) Ingold & 0.11 & 0.05 & 0.61 & 0.81 & 0.29 & 28.94 \\
\hline Articulospora tetracladia Ingold & 0.62 & 0.07 & 0.18 & 0.02 & 0.44 & 0.12 \\
\hline Campylospora ?filicladia Nawawi & & & 0.01 & & & \\
\hline Clavariopsis aquatica De Wild. & 0.32 & 0.02 & 2.25 & 0.98 & 0.26 & 0.01 \\
\hline Clavatospora longibrachiata (Ingold) Marvanová et S. Nilsson & 0.07 & 0.04 & 1.87 & 0.91 & 0.94 & + \\
\hline Culicidospora aquatica R.H. Petersen & & + & & & & \\
\hline ?Dactylella submersa (Ingold) S. Nilsson & 0.15 & 0.25 & 0.13 & 0.27 & 0.01 & 0.37 \\
\hline Flagellospora curvula Ingold & 81.06 & 86.56 & 80.37 & 38.45 & 93.19 & 63.20 \\
\hline Heliscella stellata (Ingold et Cox) Marvanová et S. Nilsson & 0.10 & 0.25 & 0.07 & 0.39 & 0.42 & 3.28 \\
\hline Heliscus lugdunensis Sacc. et Thérry & 3.61 & 1.42 & 0.09 & 1.96 & 0.37 & 1.64 \\
\hline Heliscus tentaculus Umphlett & & & 0.08 & 0.03 & & \\
\hline Lemonniera aquatica De Wild. & & + & & & 0.01 & 0.01 \\
\hline Lemonniera terrestris Tubaki & & + & & & 0.01 & \\
\hline Lunulospora curvula Ingold & 2.55 & 4.93 & 4.15 & 35.92 & 1.06 & 0.36 \\
\hline Mycocentrospora acerina (Hartig) Deighton & 0.02 & + & & & & \\
\hline Tetrachaetum elegans Ingold & 9.22 & 3.44 & 4.53 & 11.06 & 0.06 & + \\
\hline Tetracladium marchalianum De Wild. & 0.25 & 0.01 & 3.06 & 1.41 & 0.20 & 0.01 \\
\hline Tricladium chaetocladium Ingold & 1.04 & 2.45 & 1.13 & 3.42 & 2.17 & 1.85 \\
\hline Triscelophorus monosporus Ingold & 0.13 & 0.05 & 0.11 & 3.09 & 0.12 & 0.05 \\
\hline Total no. of species & 15 & 18 & 17 & 15 & 16 & 15 \\
\hline
\end{tabular}

Note: Abundances lower than $0.01 \%$ are shown as a plus sign.

marked than that of the conidial production and the species richness. In contrast with the relative stability of fungal diversity on alder at all sites, a pronounced decline occurred on eucalypt in site A (weeks 3-20) concomitantly with an increase of the number of fungal species.

Flagellospora curvula Ingold largely dominated the aquatic hyphomycete assemblages on the two leaf species (Fig. 3). This was especially obvious for alder at all sites and for eucalypt at site A where the relative abundance of this species over the whole period exceeded $80 \%$ (Table 2). Flagellospora curvula was particularly dominant initially, i.e., during the first $1-3$ weeks, but generally declined thereafter (Fig. 3). However, in some situations, e.g., alder at site A and eucalypt at $\mathrm{C}$, the abundance of $F$. curvula never decreased below $50 \%$. Coinciding with the early dominance and subsequent decline of $F$. curvula, a few other species occurred during the intermediate and late stages of fungal colonization. Lunulospora curvula Ingold was the second most abundant species on average. It exhibited abundances as high as $23-46 \%$ during the late stages on eucalypt at sites A and B. It was less abundant on alder at these sites and on both species at site C. The increase of $L$. curvula abundance on eucalypt at site A clearly coincided with the lower activity of $F$. curvula; these two species represented $44-97 \%$ of the aquatic hyphomycete assemblage over the course of decomposition. A third species, Tricladium chaetocladium Ingold, also occurred from the 8th week on both alder and eucalypt but, unlike $L$. curvula, was more abundant at site $\mathrm{C}$ than at the other sites. Tetrachaetum elegans Ingold was present on both alder and eucalypt at sites A and B with average abun- dances of $3-11 \%$ but was practically absent from site C (Table 2). The same pattern was found for Heliscella stellata (Ingold et Cox) Marvanová et S. Nilsson; this species was particularly abundant on eucalypt during the last colonization stages where it represented $8-20 \%$ of the conidial pool at sites A and B. Anguillospora longissima (Sacc. et Sidow) Ingold exhibited very low percentages at sites A and B and at site C on alder but contributed up to $29 \%$ of the total conidial production on eucalypt leaves decomposing at site $\mathrm{C}$ (Table 2). All other species contributed less than $2 \%$ of the total conidial production on alder or eucalypt leaves.

Whatever the site considered, neither conidial production nor species richness and diversity exhibited a significant difference between alder and eucalypt leaves when all sampling times were considered as a whole (independent $t$ test; Table 3). These variables, however, presented some significant differences between sites depending on the leaf species and the pair of sites considered. The conidial production at site $\mathrm{B}$ was higher than at site $\mathrm{A}$ for both species and at site $\mathrm{C}$ for alder. The number of species on both species at site B exceeded those at site $\mathrm{C}$. Like the production of conidia, the fungal diversity on both litter species was higher at site B than at site A. Sites A and C did not exhibit any significant difference.

\section{Discussion}

The fact that decomposing eucalypt leaves support a fungal colonization roughly comparable with that observed on alder leaves is the most striking result of this study. Not only the 
Fig. 3. Relative abundance of the dominant species of aquatic hyphomycetes on alder (open bars) and eucalypt (solid bars) leaves at the three sites (data at week 0 not shown). Conidial production on alder at site B (week 14) and site C (week 26) could not be measured because of insufficient leaf material.

Site A

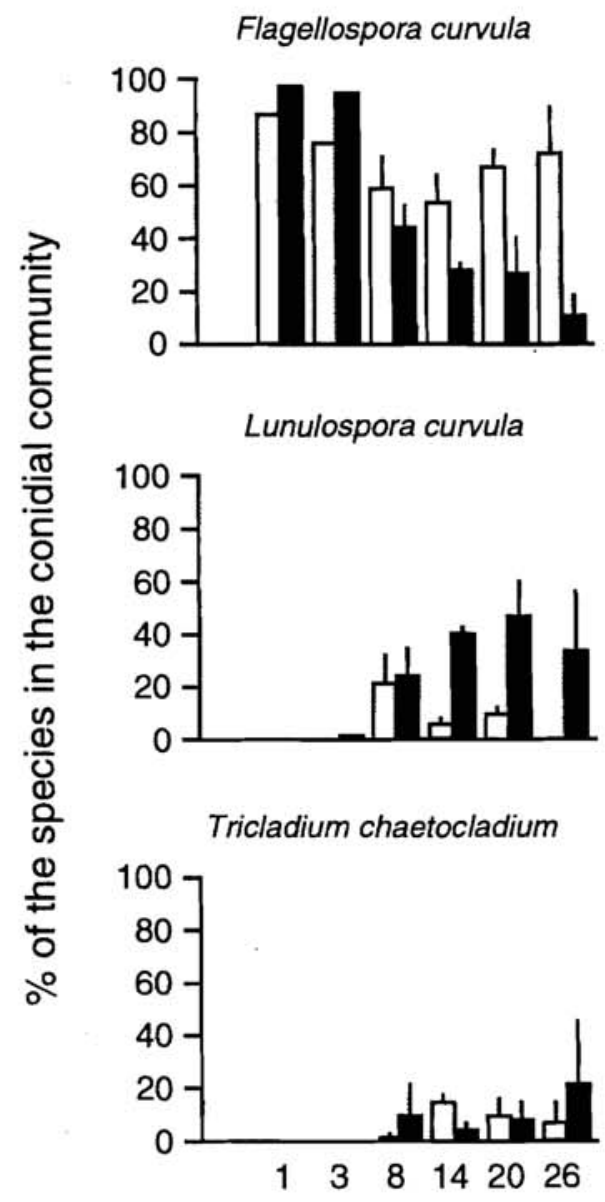

Flagellospora curvula

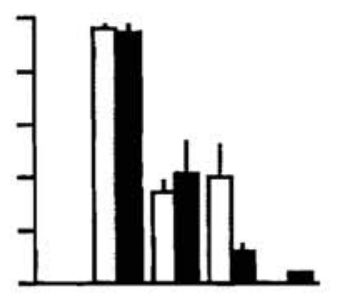

Lunulospora curvula

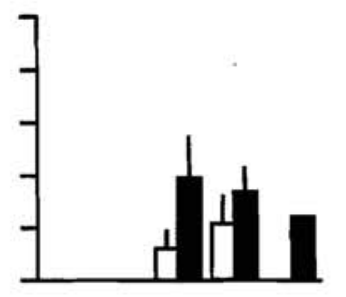

Tricladium chaetocladium

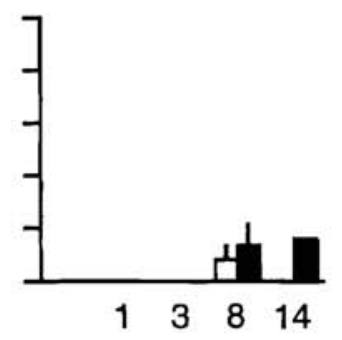

Site C

Flagellospora curvula

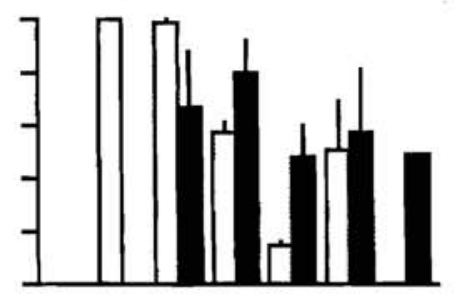

Lunulospora curvula

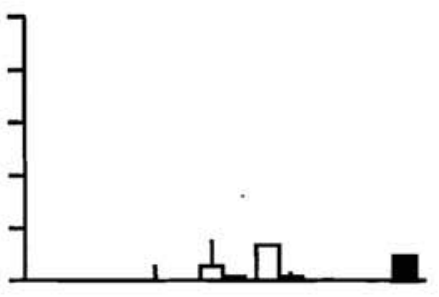

Tricladium chaetocladium

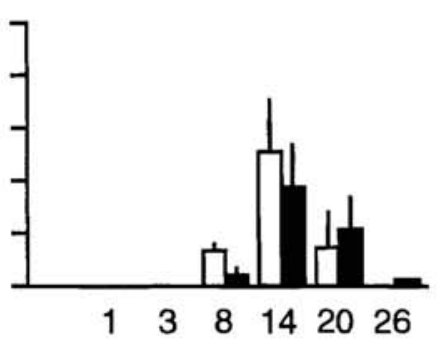

sporulation activity of aquatic hyphomycetes but also the number of fungal species and the species diversity were similar on both leaf substrata. Eucalypt, which is normally viewed as a poor-quality substratum, thus appears to be as suitable for fungal establishment as alder, a top-quality leaf species sustaining a high biological activity (Gessner and Chauvet 1994; Webster and Benfield 1986). This result contrasts with previous observations made in Australian streams where decomposing leaves of eucalypt appeared to support a poor aquatic hyphomycete flora (Bunn 1986; Cowling and Waid 1963). One of these observations was, however made on another species, Eucalyptus marginata Donn ex Sm., and was based on scanning electron microscopy (Bunn 1986). Using more appropriate techniques, recent investigations on leaves of Eucalyptus viminalis Labill. and E. globulus demonstrated that eucalypt leaves support a relatively high number of aquatic hyphomycete species (Bärlocher et al. 1995; Thomas et al. 1992). This number was comparable with that reported from leaves of $A$. glutinosa, a species widely recog-

\section{time (week)}

nized as a favorable substrate (Bärlocher et al. 1995). The conidial production from $E$. globulus leaves decomposing in the Portuguese stream studied by Bärlocher et al. (1995) was even higher than from alder leaves, a finding consistent with our data from Spanish streams. Like conifer needles and other refractory materials (Bärlocher 1992), eucalypt leaves thus are a suitable substrate for the development of aquatic hyphomycetes.

Despite this overall similarity, the fungal colonization on eucalypt was generally delayed by at least 2 weeks. A similar delay was also reported from Portugal (Bärlocher et al. 1995). This lag is probably caused by the more refractory nature of eucalypt, a feature corroborated by the longer time needed to achieve the decomposition of eucalypt leaves. One of the prevailing explanations for this delay is the higher phenolic and tannin content of eucalypt leaves compared with alder leaves (Bärlocher et al. 1995; Blackburn and Petr 1979). The rapid disappearance of these inhibitory compounds by leaching would thus explain why fungal coloniza- 
Table 3. $P$ values of independent Student $t$ test of three parameters characterizing the aquatic hyphomycete communities.

\begin{tabular}{lccc}
\hline & $\begin{array}{c}\text { Conidial } \\
\text { production }\end{array}$ & $\begin{array}{c}\text { Species } \\
\text { richness }\end{array}$ & $\begin{array}{c}\text { Species } \\
\text { diversity }\end{array}$ \\
\hline Eucalypt vs. alder & & & \\
A & $\mathrm{ns}$ & $\mathrm{ns}$ & $\mathrm{ns}$ \\
B & $\mathrm{ns}$ & $\mathrm{ns}$ & $\mathrm{ns}$ \\
C & $\mathrm{ns}$ & $\mathrm{ns}$ & $\mathrm{ns}$ \\
A vs. B & & & \\
Alder & 0.023 & $\mathrm{~ns}$ & 0.022 \\
Eucalypt & $<0.001$ & $\mathrm{~ns}$ & 0.023 \\
B vs. C & & & \\
Alder & 0.025 & 0.043 & $\mathrm{~ns}$ \\
Eucalypt & $\mathrm{ns}$ & 0.028 & $\mathrm{~ns}$ \\
A vs. C & & & \\
Alder & $\mathrm{ns}$ & $\mathrm{ns}$ & $\mathrm{ns}$ \\
Eucalypt & $\mathrm{ns}$ & $\mathrm{ns}$ & $\mathrm{ns}$ \\
\hline
\end{tabular}

Note: Comparisons are made between leaf species at each site (A, B, C), and between sites on each leaf species. $\mathrm{ns}, P \geq 0.05$.

tion attained such a high level after only the first few weeks of decomposition. When the comparison between leaf species is corrected by this effect, i.e., the variables are referred to the leaf mass remaining instead of the decomposition time, the delay of fungal dynamics on eucalypt disappears (data not shown). The apparent delay of fungal colonization on eucalypt is consequently more than counterbalanced by the lower decomposition rate of this species.

The dominance of a single species, $F$. curvula, during the first stages of decomposition is a common feature of alder and eucalypt leaves decomposing in the Agüera. Since this dominance coincided with the maximum sporulation activity observed during the first 3 weeks, $F$. curvula also appeared to be the major contributor to the overall conidial production on both alder and eucalypt. The prominence of this early colonizer has been also reported from various situations including alder leaves in a Pyrenean low-order stream (Gessner et al. 1993) and leaves of willow, poplar, and London plane in the Garonne River (Baldy et al. 1995). Other investigations from the Pyrenean stream also pointed out the initial dominance of $F$. curvula on a large variety of leaf litter ranging from the soft-textured ash leaves to tough evergreen oak leaves (E. Chauvet and M.O. Gessner, unpublished data). Since $F$. curvula colonizes eucalypt leaves as well (present data), this aquatic hyphomycete can be considered to be a generalist species unaffected by the nature of the leaf material. Although present at significant levels, $F$. curvula did not appear to exceed $25 \%$ of the conidial production in the Portuguese streams (Bärlocher et al. 1995), where the most important species on both alder and eucalypt was L. curvula, a species also present but to a lesser extent in the Agüera. The difference observed between these two regions of the Iberian Peninsula could be attributed to the wellknown affinity of $L$. curvula for warm regions, such as central Portugal, and to the lower thermal optimum of F. curvula, probably more adapted to the Atlantic climate prevailing in the Basque Country (Chauvet 1991; E. Chauvet and $\mathrm{K}$. Suberkropp, unpublished data). A careful examination of the data from Bärlocher et al. (1995, Table 1) and the results from the present study suggest that $L$. curvula develops better on eucalypt than on alder; this preference is especially obvious in Ribeira do Sobral Cid and on sites A and B of the Agüera. The same preference of $L$. curvula for leaves of eucalypt ( $E$. viminalis versus Acacia melanoxylon $\mathrm{R} . \mathrm{Br}$. ex W.T. Aiton) has been reported by Thomas et al. (1992). While this probably constitutes a clear substrate preference of this species for eucalypt substrates, the reasons are still unclear (cf. Thomas et al. 1992). In their experiment in the Portuguese streams, Bärlocher et al. (1995) showed that the preliminary treatment of eucalypt leaves by acetone or by acetone and $\mathrm{NaOH}$ lowered phenolic and tannin contents, which resulted in the acceleration of the colonization by aquatic hyphomycetes (Bärlocher et al. 1995). This treatment on eucalypt leaves, however, also appeared to result in a lower proportion of $L$. curvula (Bärlocher et al. 1995, Table 1). A possible explanation may be that $L$. curvula is less sensitive than the other species of aquatic hyphomycetes to the inhibitory effect of the leaf compounds that were removed by this treatment. Recent investigations on the effect of leaf extracts from Populus balsamifera L. on soils have shown that, while tannins inhibited the microbial activity, phenolics in contrast acted as a growth substrate for the microbial biota (Schimel et al. 1996). Although these observations cannot be directly extrapolated to lotic environments, it is clear that more studies are needed to determine the specific impact of these leaf compounds on leaf-associated microfungi.

Fungal colonization of leaf litter was clearly influenced by the environmental conditions since both alder and eucalypt decomposed faster and exhibited a much higher conidial production in the third-order stream (site B) than on the two first-order streams. Since decomposing leaves at site B immobilized more nitrogen and phosphorus than leaves from the upper reaches, the difference in decomposition rate was attributed to the nutrient contents of the stream water (Pozo 1993). Site B had concentrations of dissolved phosphorus three times higher on average than those from the upper reaches, and given the high atomic ratios of inorganic N/P at all sites (N/P > 100), phosphorus was potentially limiting. This finding is consistent with a previous investigation highlighting the importance of nutrients in stream water, which appear to regulate leaf decomposition by affecting the activity of fungal decomposers (Suberkropp and Chauvet 1995). An environmental factor that can contribute to a selection of fungal species is the conidial inoculum produced from the leaf litter naturally accumulating in the stream bed. This inoculum is thus directly influenced by the surrounding vegetation. The consistently lower species diversity observed on eucalypt compared with alder at site C (exclusively surrounded by eucalypt) as well as the marked distributional patterns of species like $H$. stellata, $L$. curvula, Tetrachaetum elegans, and Tricladium chaetocladium might be a consequence of such an effect. The reasons for which an "eucalypt-specialized" inoculum creates fungal assemblages less diverse on eucalypt than on alder remain obscure. The same observation was not made in the reciprocal situation, i.e., at site A surrounded by the native forest (but not exclusively dominated by alder). Although species-specific relationships between aquatic hyphomycetes and their leaf substrates remain unlikely, substrate preferences among fungal species can nevertheless be responsible for such an 
effect. Another explanation could be the difference of timing of leaf fall between alder and eucalypt.

In conclusion, neither a diminution nor an increase of aquatic hyphomycete conidial production, in contrast to a recent study in Portugal, was observed on eucalypt leaf litter decomposing in the Agüera. A delay of fungal colonization of the exotic substrate by about 2 weeks was, however, confirmed, but this delay did not fundamentally differ from that observed from other refractory leaf species (Gessner and Chauvet 1994). The richness of fungal assemblages was generally not affected by the change from alder to eucalypt. However, the replacement of mixed forests by monocultural stands of eucalypt combined with substrate preferences (e.g., L. curvula preference for eucalypt) may result in a modification of the conidial inoculum, which potentially controls the establishment of new fungal assemblages on leaves. More studies on the selection effect of fungal species by forestry practices are needed before this hypothesis may be generalized. In summary, the activity of aquatic hyphomycetes on leaves appeared to be more affected by the chemistry of the stream water than by a switch from the native species to the introduced one.

\section{Acknowledgments}

We thank Ana Basaguren for her help during this study and Mike Dobson for constructive reading of the manuscript. This research was supported by grant No. PB92-0459 from the DGICYT, Spanish Ministry of Education and Science.

\section{References}

Abelho, M., and Graça, M.A.S. 1996. Effect of Eucalyptus afforestation on leaf litter dynamics and macroinvertebrate community structure of streams in Central Portugal. Hydrobiologia, 324: 195-204.

Baldy, V., Gessner, M.O., and Chauvet, E. 1995. Bacteria, fungi and the breakdown of leaf litter in a large river. Oikos, 74: 93-102.

Bärlocher, F. 1992. Research on aquatic hyphomycetes: historical background and overview. In The ecology of aquatic hyphomycetes. Edited by F. Bärlocher. Springer-Verlag, Berlin. pp. $1-15$.

Bärlocher, F., Canhoto, C., and Graça, M.A.S. 1995. Fungal colonization of alder and eucalypt leaves in two streams in central Portugal. Arch Hydrobiol. 133: 457-470.

Basaguren, A., and Pozo, J. 1994. Leaf litter processing of alder and eucalyptus in the Aguera stream system (northern Spain) II. Macroinvertebrates associated. Arch. Hydrobiol. 132: 57-68.

Blackburn, W.M., and Petr, K. 1979. Forest litter decomposition and benthos in a mountain stream in Victoria, Australia. Arch. Hydrobiol. 86: 453-498.

Bunn, S.E. 1986. Origin and fate of organic matter in Australian upland streams. In Limnology in Australia. Edited by P. De Deckker and W.D. Williams. Junk, Dordrecht, The Netherlands. pp. 277-291.

Chauvet, E. 1991. Aquatic hyphomycete distribution in south-western France. J. Biogeogr. 18: 699-706.

Cowling, S.W., and Waid, J.S. 1963. Aquatic hyphomycetes in Australia. Aust. J. Sci. 26: 122-123.

Cummins, K.W. 1988. The study of stream ecosystems: a functional view. In Concepts of ecosystem ecology. Edited by L.R. Pomeroy and J.J. Alberts. Springer-Verlag, New York. pp. 247-262.

Elósegui, A., and Pozo, J. 1994. Spatial versus temporal variability in the physical and chemical characteristics of the Aguera stream (northern Spain). Acta Oecol. 15: 543-559.

Gessner, M.O., and Chauvet, E. 1994. Importance of stream microfungi in controlling breakdown rates of leaf litter. Ecology, 75: $1807-1817$.

Gessner, M.O., Thomas, M., Jean-Louis, A.-M., and Chauvet, E. 1993. Stable successional patterns of aquatic hyphomycetes on leaves decaying in a summer cool stream. Mycol. Res. 97: $163-172$.

Gonzáles, E., Elósegui, A., and Pozo, J. 1994. Changes in the physico-chemical characteristics of the Agüera streamwater associated with human settlements. Verh. Int. Ver. Theor. Angew. Limnol. No. 25. pp. 1733-1738.

Hurlbert, S.H. 1971. The non-concept of species diversity: a critique and alternative parameters. Ecology, 52: 577-586.

Krebs, C.J. 1989. Ecological methodology. HarperCollins Publisher, New York.

Maltby, L. 1992. Detritus processing. In The rivers handbook. Hydrological and ecological principles. Vol. 1. Edited by P. Calow and G.E. Petts. Blackwell, Oxford, U.K. pp. 331-353.

Mitchell, A. 1974. A field guide to the trees of Britain and Europe. Collins \& Sons Ltd., London, U.K.

Pozo, J. 1993. Leaf litter processing of alder and eucalyptus in the Agüera stream system (North Spain). I Chemical changes. Arch Hydrobiol. 127: 299-317.

Pozo, J., Basaguren, A., Elósegui, A., Molinero, J., Fabre, E., and Chauvet, E. 1997. Afforestation with Eucalyptus globulus and leaf litter decomposition in streams of northern Spain. Hydrobiologia. In press.

Schimel, J.P., Van Cleve, K., Cates, R.G., Clausen, T.P., and Reichardt, P.B. 1996. Effects of balsam poplar (Populus balsamifera) tannins and low molecular weight phenolics on microbial activity in taiga floodplain soil: implications for change in N cycling during succession. Can. J. Bot. 74: 84-90.

Shannon, C.E., and Weaver, W. 1949. The mathematical theory of communication. University of Illinois Press, Urbana, Ill.

Suberkropp, K., and Chauvet E. 1995. Regulation of leaf breakdown by fungi in streams: influences of water chemistry. Ecology, 76: $1433-1445$.

Thomas, K., Chilvers, G.A., and Norris, R.H. 1992. Aquatic hyphomycetes from different substrates: substrate preference and seasonal occurrence. Aust. J. Mar. Freshwater Res. 43: $491-509$.

Webster, J.R., and Benfield, E.F. 1986. Vascular plant breakdown in freshwater ecosystems. Annu. Rev. Ecol. Syst. 17: 567-594. 